\title{
Clinical aspects of congenital syphilis with Hutchinson's triad
}

\author{
Larissa Pessoa, ${ }^{1}$ Virgilio Galvão² \\ ${ }^{1}$ Department of Medical Sciences, University of Brasilia, Brasília, Brazil; \\ 2Department of Stomatology, Catholic University of Brasilia, Brasilia, Brazil
}

Correspondence to Professor Larissa Pessoa, lapessoa@globo.com

\section{Summary}

Congenital syphilis is an infectious disease caused by Treponema pallidum transmitted by infected mother to her baby during pregnancy. Late congenital syphilis is recognised with 2 or more years after birth. One of the main aspects is observed with the triad of Hutchinson, characterised by the presence of interstitial keratitis, eighth nerve deafness and Hutchinson's teeth. This manuscript reports a case of late congenital syphilis presenting with Hutchinson's triad at an age of 7 years. These clinical features are related to syphilis present during pregnancy and at birth, however they commonly become apparent after 5-years of age.

\section{BACKGROUND}

Congenital syphilis is an infectious disease transmitted by an infected mother to her fetus. ${ }^{1}$ In Brazil, prevalence of mother's infection is associated with poor socio-economic conditions, socially excluded and with a low educational level. ${ }^{2}$ To prevent congenital syphilis, serologic screening for syphilis is recommended at least twice during pregnancy, how soon after conception and after 28 weeks. ${ }^{3}$

Most of the clinical signs of congenital syphilis develop later. ${ }^{4}$ Manifestations of this disease include mainly the triad of Hutchinson, characterised by interstitial keratitis, eighth nerve deafness and Hutchinson's teeth. The dental defect represents a single disruption to tooth crown formation a few weeks after birth or during the later development of the teeth, ${ }^{4}$ however they only become apparent with the eruption of the permanent incisors and first molars around 6 years of age. ${ }^{5-7}$ That is why this particular form of dental defect was not found on deciduous teeth. ${ }^{5}$ This process of dental defect is explained by inflammatory reaction induced by Treponema pallidum. The invasion of bacteria to proximity of dental germ in development conduct to inhibition of ameloblasts, the cells responsible for formation of tooth enamel. ${ }^{5}$ Other oral manifestations such as premature loss of primary

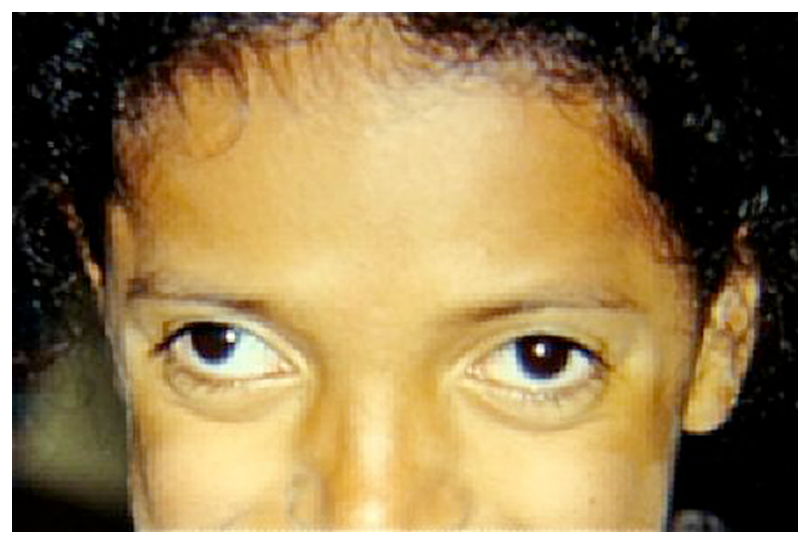

Figure 1 Interstitial keratitis and strabismus. teeth associated with congenital syphilis ${ }^{8}$ and palatal perforation ${ }^{9}$ were reported.

Interstitial keratitis (usually between 5 and 20 years of age) can lead to glaucoma or corneal scarring (an injury of the cornea of the eye that causes opacity and visual impairment). ${ }^{10}$ These effects of corneal scarring can vary from blurring to blindness in the eye. The thin sclera composed of immature collagen is more translucent than normal, so that the underlying pigment becomes visible, resulting in the blue appearance of the sclera. Keratitis may respond to corticosteroids but not antibiotic therapy. ${ }^{10}$ Eighth nerve deafness often starts with high frequency hearing loss when the child is between 8 and 10 years of age. ${ }^{11}$ However, there is low number of survivors. Late congenital syphilis (recognised 2 or more years after birth) ${ }^{12}$ is a very rare clinical entity. ${ }^{13}$ In live born infants, most deaths from congenital syphilis occur in the first weeks of life. ${ }^{14}$

\section{CASE PRESENTATION}

A 7-year-old female presented with her mother to the clinic with the complaints of poor dental esthetics. The patient was diagnosed with late congenital syphilis (2 years after

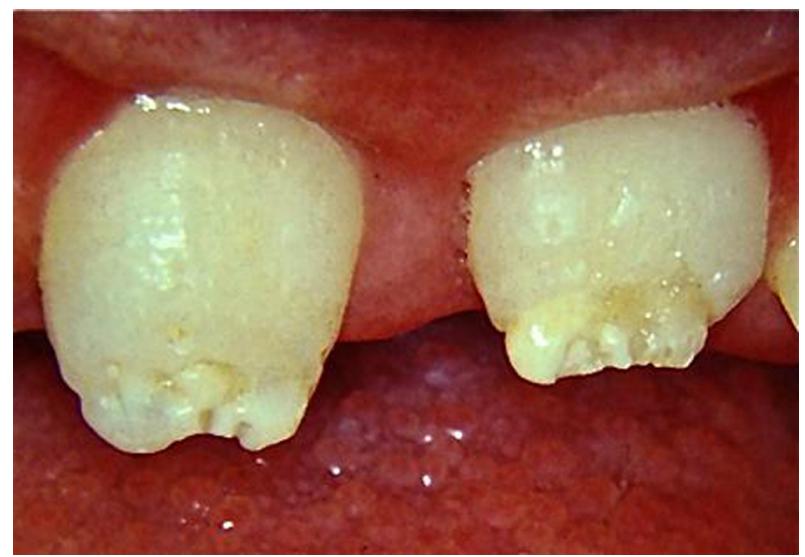

Figure 2 Enamel hypoplasia of maxillary central incisors (Hutchinson's teeth). 


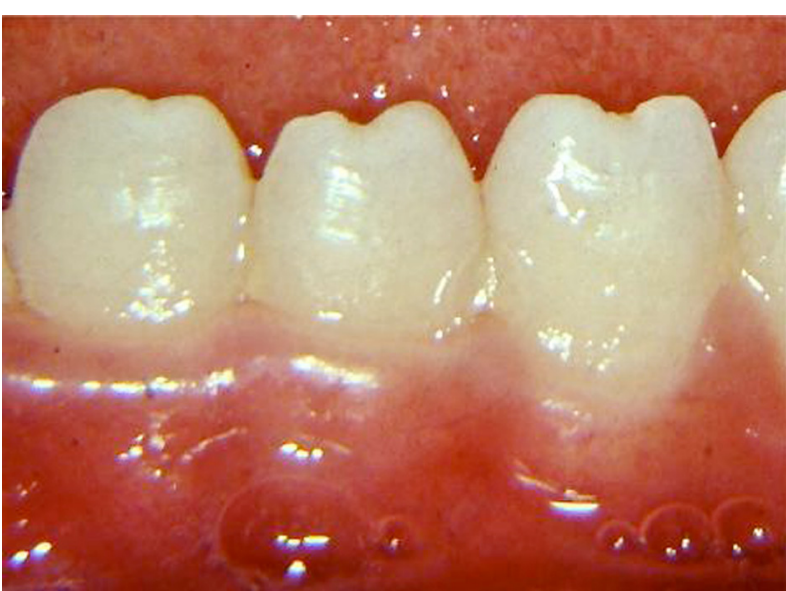

Figure 3 The semilunar notch on the incisal edge of mandibular incisors (Hutchinson's teeth).

birth). She was non-reactive for HIV. The patient was on regimen of penicillin treatment from late congenital syphilis and corticoid therapy. Hutchinson's triad was detected by the presence of interstitial keratitis (figure 1), with corneal scarring and initial presentation of bilateral blindness; deafness from auditory nerve disease and dental defects (figures 2 and 3 ).

Restorations in posterior teeth were observed and it is not possible to affirm the presence of mulberry molars (figure 4). The patient's mother reported precocious loss of deciduous teeth because of dental caries.

\section{OUTCOME AND FOLLOW-UP}

The patient was under medical supervision and was referred to the paediatric dental clinic for restorative treatment of anterior teeth.

\section{DISCUSSION}

Congenital syphilis sometimes is undiagnosed and often inadequately treated. ${ }^{14}$ It is also associated with poor socio-economic conditions with a low educational level, ${ }^{2}$ as demonstrated in the case report presented, with the several complications of disease.

Most of the clinical signs of congenital syphilis were developed later, ${ }^{4} 2$ years after birth. All the characteristics of Hutchinson's triad were identified. ${ }^{4-7}$ Interstitial keratitis was diagnosed when she was 6 -year-old, ${ }^{10}$ with a bad prognosis. Although eighth nerve deafness often starts when the child is between 8 and 10 years of age, ${ }^{11}$ the patient had hearing loss when she was 6-years-old.

In the case reported, dental defects were observed only on anterior teeth. This finding is associated of degenerative changes in the enamel epithelium induced by $T$ pallidum, leading to the complete destruction of the ameloblasts during odontogenesis. As a result, formation of abortive enamel and also cessation of enamel production occurred. ${ }^{5}$ It was not possible to affirm the presence of mulberry molars because of dental restorations.

Premature loss of primary teeth associated with congenital syphilis has been reported. ${ }^{8}$ However; it is not possible to affirm if this occurrence in the patient was associated with congenital syphilis or premature loss of deciduous teeth because of caries reported.

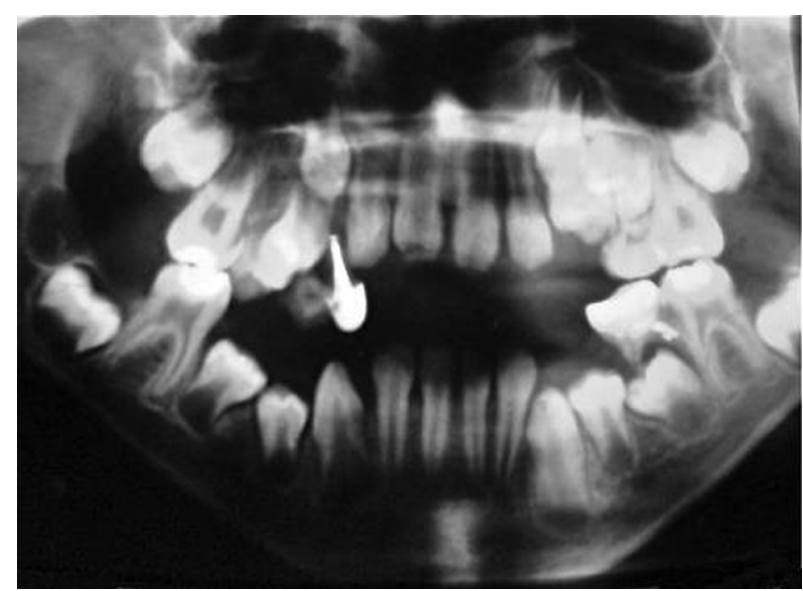

Figure 4 Panoramic radiograph: presence of restorations in posterior teeth and absence of some deciduous teeth that it is not common to see in this patient's age.

Congenital syphilis is an eminently preventable disease. In order to reduce the likelihood of its occurrence, a repeat test towards the end of gestation or at the time of delivery should be done for women in high-risk groups. ${ }^{1}$

\section{Learning points}

- Congenital syphilis reflects a failure of prenatal care systems and syphilis control programs as found in this case reported.

- Detection and appropriate timely penicillin treatment is a highly effective intervention to reduce this infection disease, avoiding significant morbidity in the future.

- Hutchinson's triad usually becomes apparent after 5 -years of age.

\section{Competing interests None.}

Patient consent Obtained.

\section{REFERENCES}

1. Blencowe H, Cousens S, Kamb M, et al. Lives Saved Tool supplement detection and treatment of syphilis in pregnancy to reduce syphilis related stillbirths and neonatal mortality. BMC Public Health 2011;11 Suppl 3:S9.

2. Madi JM, Souza Rda S, Araújo BF, et al. Prevalence of toxoplasmosis, HIV, syphilis and rubella in a population of puerperal women using Whatman 903 filter paper. Braz J Infect Dis 2010;14:24-9.

3. Neam u S, G man G, Stanca L, et al. The contribution of laboratory investigations in diagnosis of congenital infections. Rom J Morphol Embryol 2011:52(1 Suppl):481-4

4. Curtis AC, Philpott OS. Prenatal syphilis. Med Clin North Am 1964;48:707-19.

5. Hillson S, Grigson C, Bond S. Dental defects of congenital syphilis. Am J Phys Anthropol 1998;107:25-40.

6. Bernfeld WK. Hutchinson's teeth and early treatment of congenital syphilis. Br J Vener Dis 1971;47:54-6.

7. Bauer WH. Tooth buds and jaws in patients with congenital syphilis: correlation between distribution of Treponema pallidum and tissue reaction. Am J Pathol 1944;20:297-319.

8. Antonio AG, Kelly A, Maia LC. Premature loss of primary teeth associated with congenital syphilis: a case report. J Clin Pediatr Dent 2005;29:273-6.

9. Chaudhary M, Kashyap B, Bhalla P. Congenital syphilis, still a reality in $21^{\text {st }}$ century: a case report. J Med Case Reports 2007;1:90.

10. Harcourt B. Oral disorders associated with ocular disease. II. Disorders affecting dentition. Br J Ophthalmol 1967;51:284-5. 


\section{BMJ Case Reports}

11. Woods CR. Syphilis in children: congenital and acquired. Semin Pediatr Infect Dis 2005:16:245-57.

12. Larsen SA, Steiner BM, Rudolph AH. Laboratory diagnosis and interpretation of tests for syphilis. Clin Microbiol Rev 1995;8:1-21.
13. Singhal $\mathbf{P}$, Patel P, Marfatia YS. A case of congenital syphilis with Hutchinson's triad. Indian J Sex Transm Dis 2011:32:34-6.

14. Mabey D, Peeling RW. Syphilis, still a major cause of infant mortality. Lancet Infect Dis 2011;11:654-5.

This pdf has been created automatically from the final edited text and images.

Copyright 2011 BMJ Publishing Group. All rights reserved. For permission to reuse any of this content visit http://group.bmj.com/group/rights-licensing/permissions.

BMJ Case Report Fellows may re-use this article for personal use and teaching without any further permission.

Please cite this article as follows (you will need to access the article online to obtain the date of publication).

Pessoa L, Galvão V. Clinical aspects of congenital syphilis with Hutchinson's triad. BMJ Case Reports 2011;10.1136/bcr.11.2011.5130, Published XXX

Become a Fellow of BMJ Case Reports today and you can:

- Submit as many cases as you like

- Enjoy fast sympathetic peer review and rapid publication of accepted articles

Access all the published articles

- Re-use any of the published material for personal use and teaching without further permission

For information on Institutional Fellowships contact consortiasales@bmjgroup.com

Visit casereports.bmj.com for more articles like this and to become a Fellow 